\title{
MEASUREMENT OF THE SLIP OF A GLAGIER PAST ITS SIDE WALL
}

\author{
Cambridge Austerdalsbre Expedition 1955-57, Paper No. 4
}

By J. W. GLen

(Department of Physics, Birmingham University)

\begin{abstract}
Anstract. The velocity of flow of a glacier was measured at two places where the ice margin had no moraine debris between clear ice and unfragmented rock. In one of these places the point at which the measurement was made was only about $\mathrm{I} \mathrm{m}$. from the solid rock. It was found that at both sites the ice was flowing past the rock at a velocity of the same order of magnitude as the velocity of flow in the centre of the glacier in this region. Although conditions at the side of a glacier are not the same as at the bed, this large amount of slip is evidence for a high rate of slip all along the ice-rock interface, and this is in accordance with current ideas of the flow of ice below ice falls.

Zusammenfassung. Die Strömungsgeschwindigkeit eines Gletschers ist an zwei Stellen gemessen worden, wo am Eisesrande keine Moränetrümmer zwischen klarem Eis und ungebrochenem Felsen vorhanden waren. An einer dieser Stellen war der Punkt, an dem gemessen wurde, nur ungefähr I m vom festen Felsen entfernt. Es wurde gefunden, dass die Geschwindigkeit, mit der das Eis am Felsen vorbeiströmte, an beiden Stellen von derselben Grössenordnung war wie die Strömungsgeschwindigkeit im Zentrum des Gletschers in diesem Gebiet. Obgleich die Verhältnisse am Gletscherrand nicht dieselben sind wie am Gletscherboden, so ist dieser grosse Betrag an Rutschen doch ein Beweis für eine hohe Rutschrate ganz über der Eis-Fels Zwischenfläche, und das steht im Einklang mit heutigen Anschauungen über die Eisströmung unter Gletscherbrüchen.
\end{abstract}

\section{INTRODUGTION}

The problem of the slip of a glacier on its bed is still one of the most important problems in glacier physics. It seems most probable that such slip occurs, and yet we have little idea of the physical laws which govern the amount of slip. Lagally ${ }^{\mathrm{I}}$ pointed out how such slip would affect calculations based on the viscous theory of glacier flow, while more recently Nye ${ }^{2}$ has shown how in a plastic theory such slip is necessary in extending and compressive flow conditions. Recently Weertman ${ }^{3}$ has suggested a theory to account for the slip in a glacier whose flow law is neither viscous nor pure plastic, but of the form found in laboratory tests on ice. ${ }^{4}$ Direct experimental evidence for the slip of a glacier past its bed is hard to obtain, and tunnel experiments seem to be the best way of obtaining reliable results. McCall found in his tunnel in the little corrie glacier Vesl-Skautbreen 5 that quite a large fraction of the total movement was due to slip over the bed or shear in a very narrow layer of ice adjacent to the bed. In his upper tunnel he found a gap between the ice and the rock, and where this situation occurs it is quite natural to expect that the ice will be moving past the rock with an appreciable speed.

Transverse velocity profiles of glaciers, measured on the glacier surface, have often also suggested that close to the ice margin there is a very rapid change in ice velocity, either a discontinuity at the margin itself or else a zone of very rapid shear near the edge. For example Pillewizer ${ }^{6}$ measured velocity profiles across several glaciers flowing from Jostedalsbreen, Norway, and found that in the long glaciers such as Tunsbergdalsbreen and Nigardsbreen there was no such discontinuity whereas on the shorter glaciers, Austerdalsbreen and Bødalsbreen, there was a rapid variation of velocity. This work has also been reported briefly in the Fournal of Glaciology by Finsterwalder. ${ }^{7}$ It is pointed out in these papers that the two shorter glaciers have much steeper ice falls than the long glaciers, and that this rapid change of velocity at the side below the ice falls is akin to the Block-Schollen flow introduced by Finsterwalder.

In view of these facts it was felt that, while the Cambridge Austerdalsbre Expedition was 
making measurements on the strain rate of the ice at the foot of the ice fall in 1956 , it would be useful to try to find places at which it might be possible to see to what extent this phenomenon of the rapid flow found near the margins was due to slip past the bed or to a more gradual increase in velocity over a larger distance.

\section{Description of the Sites}

At most places along the margin of Austerdalsbreen (as of most other glaciers) the exact margin between ice and solid, unmoving rock is not easy to observe, as a large amount of morainic debris covers the sides. Only in a few places is this covering of boulders not present, and this fact was largely responsible for the choice of the two sites used in the present work.

Austerdalsbreen is a valley glacier fed by two ice falls, as shown in the map (Fig. r, below).

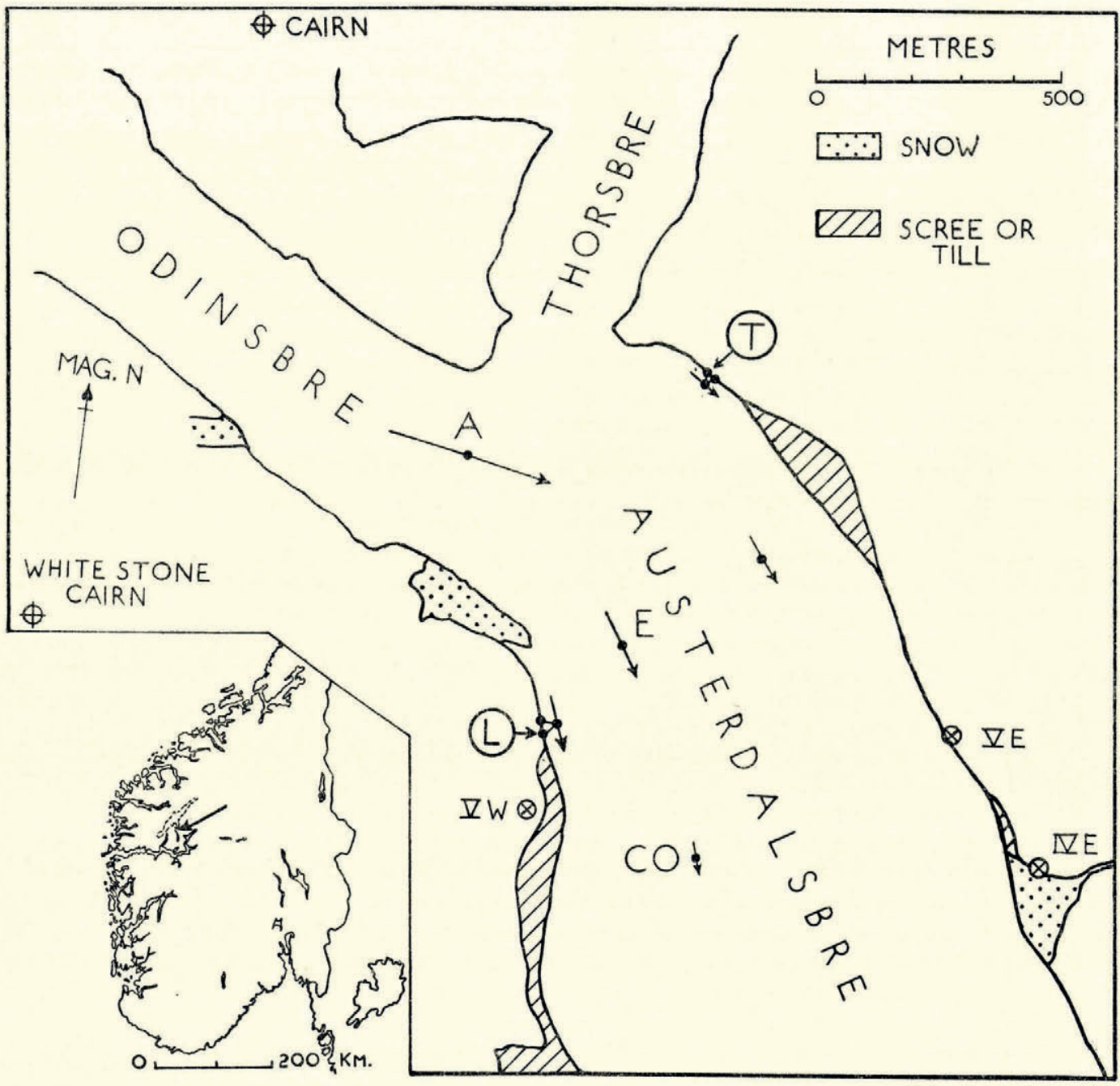

Fig. I. Map of the upper part of Austerdalsbreen showing the sites at which the velocity has been measured near the glacier margins. The arrows centred at these points, and also those in other parts of the glacier, show the velocity in metres per year plotted to the same scale as the map. The inset map shows the location of this glacier on a map of southern Norway 
Just at the foot of the ice falls two places were found, one on each of the outer margins of the glacier, at which the ice abutted directly against the solid rock wall with no intervening moraine. Unfortunately in both cases the ice was undergoing a marked bending at the points in question (marked $\mathrm{L}$ and $\mathrm{T}$ in Fig. $\mathrm{I}$ ). At the south-westerly side (point $\mathrm{L}$ ) there was a gap between the ice and the rock. This is shown in Fig. 2 (p. 193). It was of considerable depth, as was found by listening to the rolling of stones thrown down the gap. In this situation the flow of the ice past the rock could be measured on a very small scale, as the flow of a stone placed near the edge of the ice past painted marks on the rock was quite fast enough to be recorded in the course of the 24 hours that elapsed before ablation sent the stone down the gap. In order to measure flow over somewhat longer periods of time a stake was bored into the ice about $25 \mathrm{~m}$. from the rock, and its movement relative to painted marks on the rock was also surveyed.

On the north-eastern side the situation was complicated by the fact that the ice fall on this side was continuously sending down avalanche material, and that the site was near the bottom of one of the avalanche chutes. This meant that no marker placed close to the wall would survive for long, although about $15 \mathrm{~m}$. away was a region of somewhat higher ice which was not affected by the avalanche material. A stake was therefore driven into this ice, and was used to measure the flow past painted marks on the rock.

\section{Method of Measurement}

In all three cases the method employed to determine the flow of the ice was basically the same. The marker on the ice (either the paint mark on the small stone very close to the rock, or the stake) was made one vertex of a triangle, of which the other two vertices were painted survey marks on the rock. The triangles were arranged to be approximately equilateral, and their three sides were measured on several occasions; from the variations in these lengths the horizontal components of the velocity of the ice at the marker can be deduced.

In one case this method was not possible for the final observation, because flow of the ice had left one of the rock marks at an inaccessible point on the smooth rock face. In this case the distance from the stake to the other rock mark was measured, and a theodolite was used to determine the angle subtended by the two marks at the stake; as the triangle was known to be acute-angled, and as the distance between the two fixed marks was known from earlier surveys, this gave sufficient data to calculate the flow.

\section{Results}

The values obtained for the lengths in the various surveys are shown in Table I (p. I 92 ). It will be seen that there was a steady change with time, and that the flow was quite fast enough for significant results to be obtained in a few hours. The use of the first and last surveys to determine velocities of flow over the whole period is shown in Table II, while in Table III the values obtained for the velocities in between each two surveys are shown.

From these tables it will be seen that the rock at $\mathrm{L}$ which formed the apex of the small triangle moved with an average velocity of $26 \mathrm{~cm}$. per day, and that it was only I-I5 m. horizontally from solid rock. The stake in the same region, $25.5 \mathrm{~m}$. from solid rock, moved with an average velocity of $30.0 \mathrm{~cm}$. per day, and, on the other side of the glacier, the stake $15.3 \mathrm{~m}$. from the rock at $\mathrm{T}$ had an average velocity of $20 \cdot 7 \mathrm{~cm}$. per day.

It will also be seen that within the estimated experimental error there was no significant variation of velocity with time. There is a slight suggestion that velocity might have been decreasing with time in all three sets of results in Table III, but in all cases the errors could 
be invoked to account for the differences. There is, however, a significant difference between the velocity of the two marks at $\mathrm{L}$, i.e. between the velocity $\mathrm{I} \cdot \mathrm{I} 5 \mathrm{~m}$. from the rock and that $25.5 \mathrm{~m}$. from the rock. This cannot be due to the different time spans of the two experiments, as the velocity given by measurement over the first 19.5 hours of the test on the larger triangle, which period ended at the same time as the whole test on the small triangle, also has a value which differs significantly. The difference of velocity between these two points may thus be ascribed to an increase in velocity with distance from the margin, though as the glacier is undergoing severe strains in a longitudinal direction in this part of the glacier, a direct interpretation of this result is not possible.

Because of these longitudinal strains, and because the shape of the glacier is rather complicated in this region, it is also difficult to make detailed comparison with the velocity in the centre of the glacier. There are very large changes in velocity in the central region, and these will form the subject of separate study, but for comparison with these marginal velocities, the measured velocities at stakes in the middle of the glacier and shown in Fig. I were: Stake A, $95^{\circ} \mathrm{o} \mathrm{cm}$. per day ( $346 \mathrm{~m}$. per year); Stake E, $39^{\cdot} \cdot 8 \mathrm{~cm}$. per day (145 m. per year); Stake CO, $19.4 \mathrm{~cm}$. per day (7I m. per year). The velocities found at the margins of the glacier were therefore of the same order of magnitude as those occurring in the middle, so that quite an appreciable part of the flow is still present in these marginal regions.

\section{Discussion}

The profile used by Pillewizer in his earlier determination of the velocity at the margin of Austerdalsbreen was too far down the glacier to be shown in Fig. I. The main result of the results reported here is that much closer to the ice fall the velocity at the margin was still an appreciable fraction of the velocity at the centre, and that this applied right up to the very edge of the ice, which is separated by an air gap from the bedrock. This gap clearly cannot be present at all places, but at the points where the ice does come into contact with the rock there will be intense local differential movement between ice and rock. Stones that fell onto the margin of the ice in this area were deposited by ablation into the gap, and several stones could be seen in it. These stones were being rolled by the ice between it and the rock, and were the only obvious mechanism for erosion in this region.

These observations are not necessarily evidence for slipping of the glacier past its bed at depth because the conditions will be different in the two cases, largely because of the hydrostatic pressure at depth, which, among other effects, will tend to remove any air gap that flow is tending to produce. However, the existence of these very high ice velocities so close to the rock wall is at least suggestive that at depth a similar rapid flow may be occurring next to the rock, and as the location of these sites was in a region of the glacier where such discontinuities are expected both in Nye's plastic theory and also according to Finsterwalder's more empirical Block-Schollen concept, it is comforting to see that the predictions are confirmed in so striking a way.

\section{Acknowledgements}

I should like to thank Mr. J. Burgess and Mr. J. Irving, both of the Brathay Exploration Group, for their assistance in setting up and surveying the marks used in this investigation. I am also indebted to Dr. J. F. Nye for the details concerning the velocities in the centre of the glacier and for helpful criticism, and to other members of the Expedition for help of various kinds. Finally I should like to thank all those organizations whose help made the Expedition possible, particularly the Royal Geographical Society and the Mount Everest Foundation. 
Table I. Measurements of the Lengths of the Sides of Triangles

Each triangle consisted of three marks, two of which (A and B) were fixed on solid rock and one of which (C) was moving with the glacier. The measurements were made in British units, but have here been transferred to metric units. The accuracy of a single measurement was about $\pm 0 \cdot 3 \mathrm{~cm}$. for the small triangle and about $\pm \mathrm{I} \cdot 3 \mathrm{~cm}$. for both the larger triangles.

Small Triangle at L. Time Zero: 13.50 hr., io August 1956

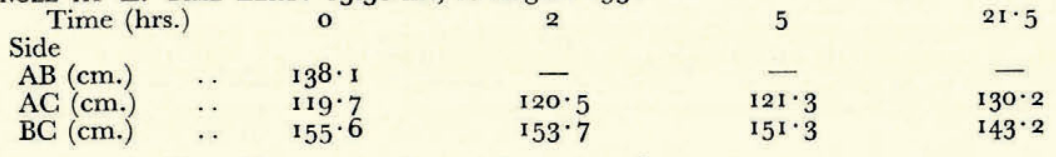

Large Triangle at L. Time Zero: $15.50 \mathrm{hr}$., 10 August $195^{6}$

$$
\text { Side }
$$
Time (hrs.)

I $5.50 \mathrm{hr}$., 10 August
19.5

$\begin{array}{ll}72 & 241 \\ - & - \\ 28 \cdot 73 & 29 \cdot 77 \\ 29 \cdot 84^{*} & 28 \cdot 50 \dagger\end{array}$

Triangle at T. Time Zero: $18.00 \mathrm{hr} .$, Io August 1956

$\begin{array}{llllll}\text { AB (m.) } & \ldots & 28 \cdot 76 & - & - & - \\ \text { AC (m.) } & \ldots & 28 \cdot 26 & 28 \cdot 39 & 28 \cdot 73 & 29 \cdot 77 \\ \text { BC (m.) } & \ldots & 29 \cdot 97 & 29 \cdot 84 & 29 \cdot 84^{*} & 28 \cdot 50 \dagger\end{array}$

Side

Time (hrs.)

$\begin{array}{lll}\text { AB (m.) } & \ldots & 16.03 \\ \text { AC (m.) } & \cdots & 15.89 \\ \text { BC (m.) } & \cdots & 18.46\end{array}$
70

$1 \overline{6 \cdot 20}$

$18 \cdot 19$
241

$17 \cdot 02$

I $7 \cdot 65$

* This figure seems inconsistent. An error of exactly I foot would make it $29 \cdot 53$, which corresponds to uniform flow very closely. This corrected value has been used in calculating the values for Table III.

+ This figure is not measured directly but calculated using the other measured sides and the measured angle $\mathrm{ACB}$ of $59^{\circ} \mathrm{O6^{ \prime }}$.

Table II. Deduction of Movement and Average Flow Velocity

In this table $x$ represents the component of position of the moving point $\mathrm{C}$ from the fixed point $\mathrm{A}$ parallel to $\mathrm{AB}$, and $y$ the component perpendicular to $\mathrm{AB}$. The suffix $\mathrm{I}$ corresponds to the first measurement, and the suffix 2 to the final measurement. $r$ is the total horizontal distance moved by $\mathrm{C}$, and $v$ the flow velocity. The indications of accuracy are deduced from the estimates of error in the experimental data given in Table I.

\begin{tabular}{|c|c|c|c|c|c|c|c|c|c|c|}
\hline Triangle & & $x_{1}$ & $y_{1}$ & $x_{2}$ & $y_{2}$ & $x_{2}-x_{1}$ & $y_{2}-y_{1}$ & $r$ & & \\
\hline Sma & & $\begin{array}{l}\mathrm{cm} . \\
33 \cdot 3\end{array}$ & cm. & cm. & cm. & $\begin{array}{l}\mathrm{cm} . \\
22 \cdot 7\end{array}$ & $\begin{array}{l}\mathrm{cm} . \\
2 \cdot 4\end{array}$ & $\begin{array}{l}\mathrm{cm} . \\
22 \cdot 9\end{array}$ & $\begin{array}{c}\mathrm{cm} \cdot / \text { day } \\
25.6 \pm 0.8\end{array}$ & $\begin{array}{c}\mathrm{m} . / \mathrm{yr} . \\
94 \pm 3\end{array}$ \\
\hline Large & . & 1265 & 2527 & 1566 & $253 \mathrm{I}$ & 301 & 4 & 301 & $30 \cdot 0 \pm 0.4$ & $110 \pm 1$ \\
\hline $\mathrm{T} \ldots$ & . & $5^{26}$ & I 499 & 733 & I 535 & 207 & 36 & 210 & $20.7 \pm 0.3$ & $76 \pm 1$ \\
\hline
\end{tabular}

Table III. Mean Velocities over Individual Time Intervals

Small Triangle at L

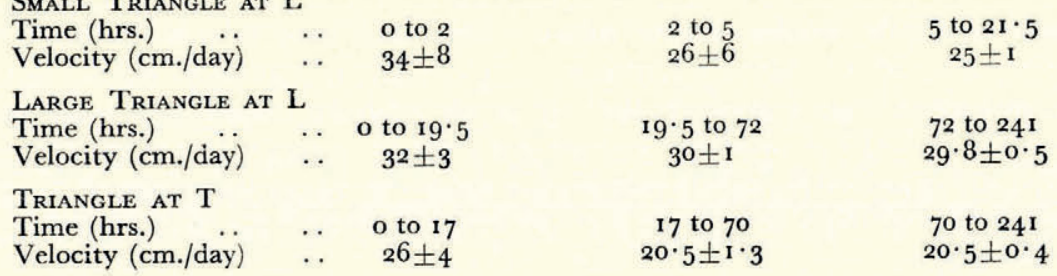

MS. received 6 December 1957

\section{REFERENCES}

1. Lagally, M. Zur Mechanik eines auf seiner Sohle gleitenden stationären Gletschers. Zeitschrift für Gletscherkunde, Bd. 26 , Ht. 3/4, 1939, p. 193-98.

2. Nye, J. F. The mechanics of glacier flow. Journal of Glaciology, Vol. 2, No. 12, 1952, p. 82-93.

3. Weertman, J. On the sliding of glaciers. Journal of Glaciology, Vol. 3, No. 2 1, 1 957, p. 33-38.

4. Glen, J. W. The creep of polycrystalline ice. Proceedings of the Royal Society, Ser. A, Vol. 228, No. I 175,1955 , p. 519-38.

5. 'McCall, J. G. The internal structure of a cirque glacier, report on the studies of englacial movements and temperatures. Fournal of Glaciology, Vol. 2, No. 12, 1952, p. 122-30.

6. Pillewizer, W. Bewegungsstudien an Gletschern der Jostedalsbre in Südnorwegen. Erdkunde, Bd. 4, Ht. 3/4, 1950, p. 20 I-o6.

7. Finsterwalder, R. The glaciers of Jostedalsbreen. Journal of Glaciology, Vol. r, No. I0, 1951, p. 557-58. 


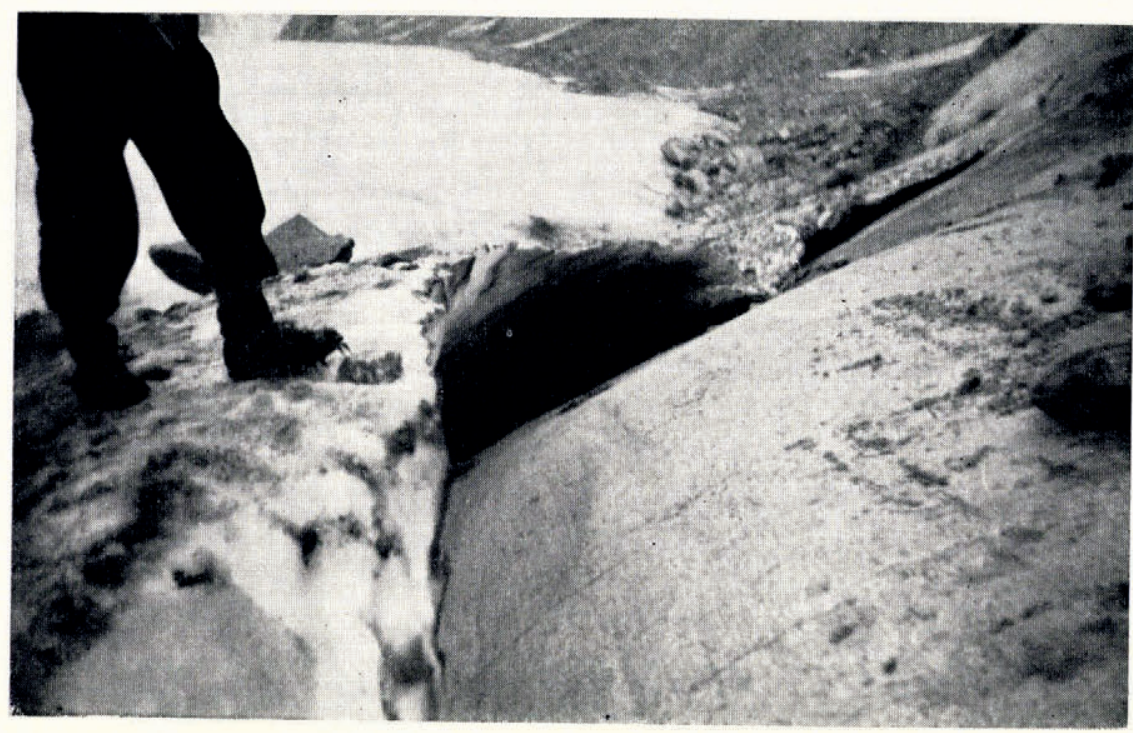

Fig. 2. View of the right margin of Austerdalsbreen at the point $L$ at which the velocity of the ice was measured. The small triangle had its moving mark on the small stone in front of the foot in the picture. Note the air gap between ice and rock in this region. (Photograph by $\mathbf{7}$. Burgess)

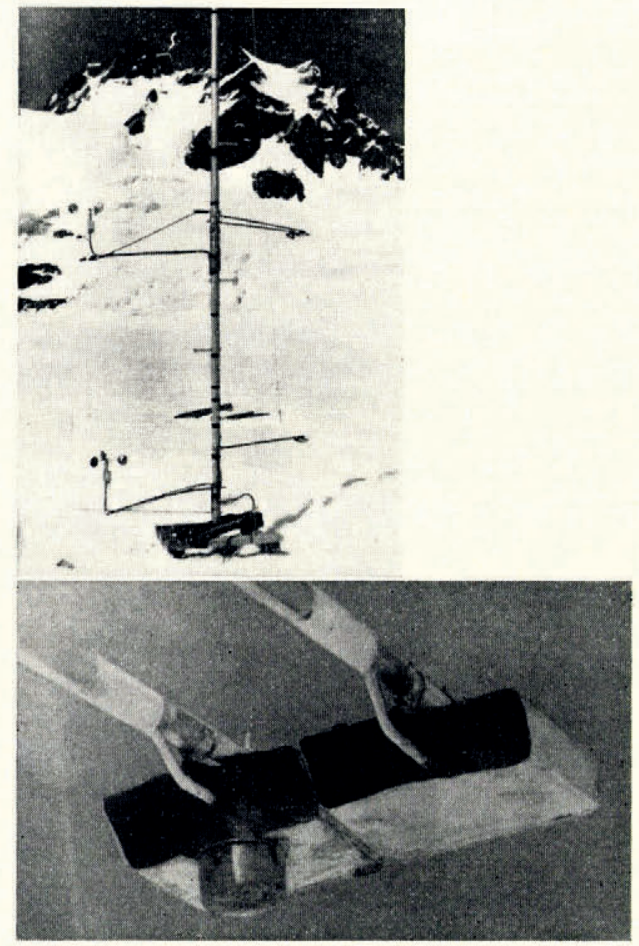

Fig. 5. The lower thermocouples and anemometers on the meteorological mast

Fig. 6. The wet and dry thermocouples at $213 \mathrm{~cm}$.

See C. J Adkins-The Summer Climate in the Accumulation Area of the Salmon Glacier, p. 195. 